\title{
Analisis pH dan Pengadukan Terhadap Produksi Biogas dari Limbah Cair Kelapa Sawit
}

\author{
pH and Agitation Analisys of Biogas Production from Palm Oil Mill Effluent \\ (POME)
}

\author{
Faizah Suryani $^{*}$, Ozkar Firdausi Homsah ${ }^{2}$, Mahmud Basuki ${ }^{3}$ \\ 1,2)Fakultas Teknik Jurusan Teknik Industri Universitas Tridinanti Palembang \\ 3)Jurusan Teknik Mesin Universitas Tridinanti Palembang \\ Jl. Kapten Marzuki No. 2446 Palembang. (0711) 354654 \\ *email: faizahsuryani.fs@gmail.com
}

\begin{abstract}
ABSTRAK
Histori Artikel:

Submitted:

25/09/2017

Accepted:

$18 / 05 / 2018$

Published:

02/06/2018

Limbah Cair Kelapa Sawit (Palm Oil Mill Effluent/POME) merupakan salah satu sumber yang berpotensi untuk diolah menjadi biogas karena kandungan gas metana yang tinggi. Selain itu ketersediaan limbah cair kelapa sawit ini cukup memadai seiring dengan berkembangnya industri minyak kelapa sawit di Indonesia. Pada tahun 2014, luas kebun kelapa sawit mencapai 10,9 Ha dengan produksi 29,3 juta ton CPO. Penelitian ini dilakukan untuk melihat pengaruh $\mathrm{pH}$ dan pengadukan pada digester untuk mendapatkan hasil biogas yang optimal. Percobaan dilakukan dengan membuat digester bervolume $3 \mathrm{~L}$, dioperasikan pada temperatur kamar, dengan mevariasikan pH 7,5;8 dan 8,5, waktu fermentasi $7,10,13,15$ dan 17 hari dan memakai digester berpengaduk dan tidak berpengaduk. Pada larutan ditambahkan $\mathrm{NaOH}$ sebagai pengatur $\mathrm{pH}$ larutan agar sesuai dengan kondisi yang diinginkan. Kondisi yang paling baik dalam menghasilkan biogas adalah pH 8,5 waktu fermentasi 13 hari dengan digester berpengaduk, dengan konsentrasi biogas sebesar 195,41 ppm.
\end{abstract}

Kata Kunci: biogas ,limbah cair kelapa sawit, pH, fermentasi anaerob

\begin{abstract}
Palm Oil Mill Effluents (POME) is one potential sources to produce biogas that has high methane gas content. In addition, the availibility of POME is quite sufficient as the development of palm oil industry in Indonesia. In 2014, the area of palm oil plantation reaches 10,9 Ha with total production of CPO about 29,3 million tons. This research was define to measuring the effect of $\mathrm{pH}$ and string on the digester to produce optimal biogas. Digester was operated at room temperature This experiment was operated by preparing $3 \mathrm{~L}$ digesters by varying pH 7,5; 8 and 8,5 and fermentation time of 7, 10, 13, 15 and 17 days, using stirred and non-stirred digester. In POME added $\mathrm{NaoH}$ as a pH regulator to suit the desired condition. The results obtained of best parameter for producing biogas with pH 8,5 and 13 days fermentation time using stirred digester that produce biogas 195,41 ppm.
\end{abstract}

Keywords: biogas, Palm Oil Mill effluent, $\mathrm{pH}$, anaerob fermentation

\section{PENDAHULUAN}

Kebutuhan energi semakin lama semakin meningkat seiring bertambahnya jumlah manusia. Sementara sumber energi yang tersedia jumlahnya semakin lama semakin berkurang. Sumber energi utama yang masih di gunakan adalah energi yang berasal dari fosil, seperti minyak bumi, batubara dan gas alam. Oleh karena itu manusia mulai mengembangkan sumber energi alternatif yang bisa mengantikan dominasi sumber 
energi fosil, seperti energi dari biomassa. Untuk mendukung sumber energi alternatif, pemerintah mulai membuat langkah-langkah strategis untuk mengatasi kelangkaan sumber daya minyak bumi, salah satunya dengan cara membuat Kebijakan Energi Nasional 20072025. Kebijakan ini menitik beratkan pada diversifikasi sumber daya energi (DESDM,2005)

Indonesia merupakan negara tropis dengan sumber daya alam yang melimpah sebenarnya mampu untuk mengembangkan sumber energi alternatif pengganti energi fosil, terutama yang bersumber dari biomassa. Apalagi dengan berkembangnya industri minyak goreng yang berasal dari kelapa sawit. Menurut data dari Ditjen Perkebunan (2015), sampai tahun 2014 luas area kelapa sawit mencapai 10,9 juta Ha dengan produksi 29,3 juta ton CPO. Proses produksi limbah cair kelapa sawit menghasilkan limbah padat dan limbah cair, yang sangat mencemari lngkungan apabila dibuang secara langsung. (DESDM,2005)

Limbah padat pabrik kelapa sawit berupa cangkang serta fiber yang selama ini dipakai untuk bahan bakar boiler, dan tandan kosong yang dipergunakan kembali untuk pupuk (mulsa) bagi tanaman. Sedangkan limbah cair biasanya langung dibuang ke kolam pembuangan dan dibiarkan tanpa proses penanganan lebih lanjut. Padahal limbah cair kelapa sawit tersebut mengandung metana $\left(\mathrm{CH}_{4}\right)$ (Deublein dan Steinhauster, 2008). Pada saat limbah mengami fermentasi anaerob di dalam kolom, gas metana terlepas ke udara dan dilepaskan ke atmosfer secara langsung. Menurut Sumirat (2009) salah satu penyebab terjadinya perubahan iklim adalah karena makin banyaknya kandungan gas rumah kaca di atmosfir. Gas-gas rumah kaca (GRK) di atmosfir antara lain $\mathrm{CO}_{2}, \mathrm{CH}_{4}, \mathrm{CF}_{\mathrm{C}}$, dan $\mathrm{N}_{2} \mathrm{O}$. Gas $\mathrm{N}_{2} \mathrm{O}$ mempunyai kemampuan merusak lapisan ozon di stratosfer melalui proses fotolisis. Gas metana merupakan sumber pemanasan global 21 kali dari gas $\mathrm{CO}_{2}$

Limbah cair kelapa sawit atau Palm Oil Mill Effluent (POME) merupakan buangan dari pabrik pengolahan kelapa sawit, POME ini masih mengandung berbagai jenis senyawa seperti serat, protein dan senyawa lain. Hal ini dapat dilihat pad Tabel 1 tentang sifat dan komponen POME secara umum (Ngan, 2000)
Tabel 1. Sifat dan komponen POME

\begin{tabular}{lc}
\hline Parameter & Rata-rata (mg/l) \\
\hline $\mathrm{pH}$ & 4.7 \\
minyak & 4000 \\
$\mathrm{BOD}$ & 25000 \\
$\mathrm{COD}$ & 50000 \\
Total Solid & 40500 \\
Suspended Solid & 18000 \\
Total Volatile Solid & 34000 \\
Nitrogen & 750 \\
\hline
\end{tabular}

Baku mutu Limbah cair pada industri minyak kelapa sawit yang diperkenankan untuk dibuang ke lingkungan diatur oleh Keputusan menteri lingkungan hidup N0.51 Tahun 1995. Keterangan lebih lengkap mengenai baku mutu lingkungan limbah cair kelapa sawit dapat dilihat pada Tabel 2.

Tabel 2. Baku Mutu Limbah Cair Industri

\begin{tabular}{|c|c|c|}
\hline Parameter & $\begin{array}{c}\text { Kadar } \\
\text { Maksimum } \\
(\mathrm{Mg} / \mathrm{l})\end{array}$ & $\begin{array}{c}\text { Beban } \\
\text { Pencemaran } \\
\text { Maksimum } \\
\text { (Kg/Ton) }\end{array}$ \\
\hline COD & 350 & 0,25 \\
\hline BOD & 100 & 0,88 \\
\hline TSS & 250 & 0,63 \\
\hline $\begin{array}{l}\text { Minyak dan } \\
\text { Lemak } \\
\text { Nitrogen }\end{array}$ & 25 & 0,063 \\
\hline Total & 50 & 0,125 \\
\hline Nikel & \multicolumn{2}{|c|}{$0,5 \mathrm{mg} / \mathrm{l}$} \\
\hline $\begin{array}{l}\text { Kobalt } \\
\mathrm{pH}\end{array}$ & \multicolumn{2}{|c|}{$0,6 \mathrm{mg} / \mathrm{l}$} \\
\hline
\end{tabular}

(Kementrian Lingkungan Hidup, 2017)

\section{METODOLOGI PENELITIAN}

Bahan yang digunakan pada penelitian ini adalah limbah cair kelapa sawit (POME) yang didapatkan dari pabrik kelapa sawit di daerah Banyuasin Sumatera Selatan, Natrium hidroksida $(\mathrm{NaOH})$, aktivator pembangkit metana. Alat yang digunakan pada penelitan ini dapat dilihat pada Gambar 1. 


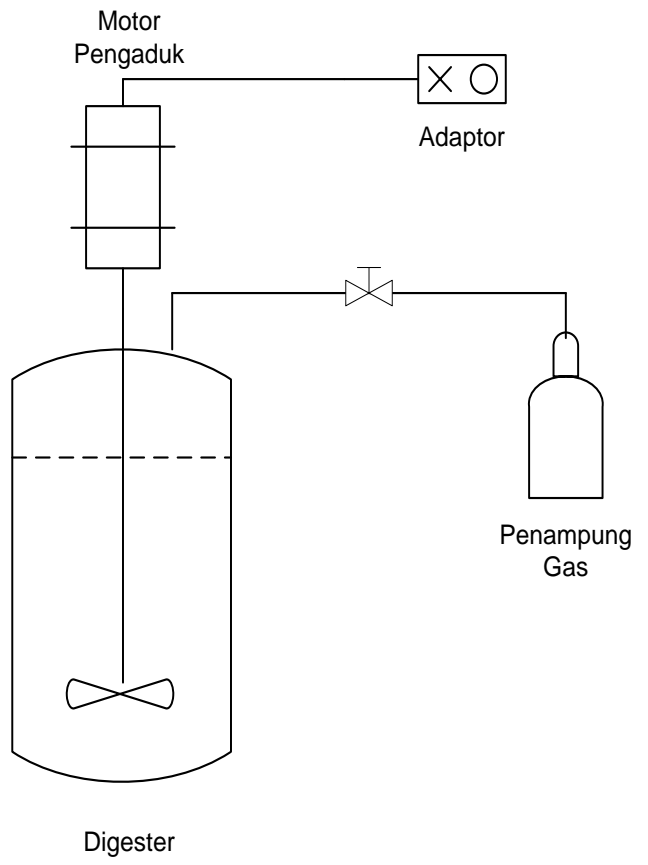

Gambar 1. Peralatan Pembuatan Biogas

Percobaan ini dilakukan pada volume digester $3 \mathrm{~L}$ dan temperatur kamar, dan kondisi anaerob dengan memvariasikan waktu fermentasi dan $\mathrm{pH}$ serta pengadukan pada digester. Waktu fermentasi yang dipakai adalah $7,9,11,13,15$ dan 17 hari dan hari serta pH 7; 7,5; 8 dan 8,5. Untuk menetralkan $\mathrm{pH}$ pada larutan dilakukan penambahaan $\mathrm{NaOH}$.

\section{HASIL DAN PEMBAHASAN}

Biogas merupakan gas yang dihasilkan dari proses fermentasi bahan-bahan organik, biogas dapat terbentuk tanpa adanya oksigen (anaerob). Bahan-bahan organik yang dapat menghasilkan biogas, misalnya limbah domestik, kotoran hewan dan juga limbah cair kelapa sawit. Kandungan utama dari biogas adalah gas Metana yang dapat dipergunakan sebagai sumber bahan bakar. Kandungan biogas secara umum dapat dilihat pada Tabel 3.

Tabel 3. Kandungan biogas secara umum

\begin{tabular}{ll}
\hline Komponen & $\%$ \\
\hline Metana $\left(\mathrm{CH}_{4}\right)$ & $55-57$ \\
Karbon Dioksida $\left(\mathrm{CO}_{2}\right)$ & $25-45$ \\
Nitrogen $\left(\mathrm{N}_{2}\right)$ & $0-0.3$ \\
Hidrogen $\left(\mathrm{H}_{2}\right)$ & 1.5 \\
Hidrogen sulfida $\left(\mathrm{H}_{2} \mathrm{~S}\right)$ & $0-0.3$ \\
Oksigen $\left(\mathrm{O}_{2}\right)$ & $0.1-0.5$ \\
\hline (Deublein dan Steinhauster, 2008$)$
\end{tabular}

\section{Pengaruh pH Terhadap Konsentrasi Biogas}

Pengaruh $\mathrm{pH}$ terhadap konsentrasi biogas yang dihasilkan dapat dilihat pada Gambar 2 dan Gambar 3.

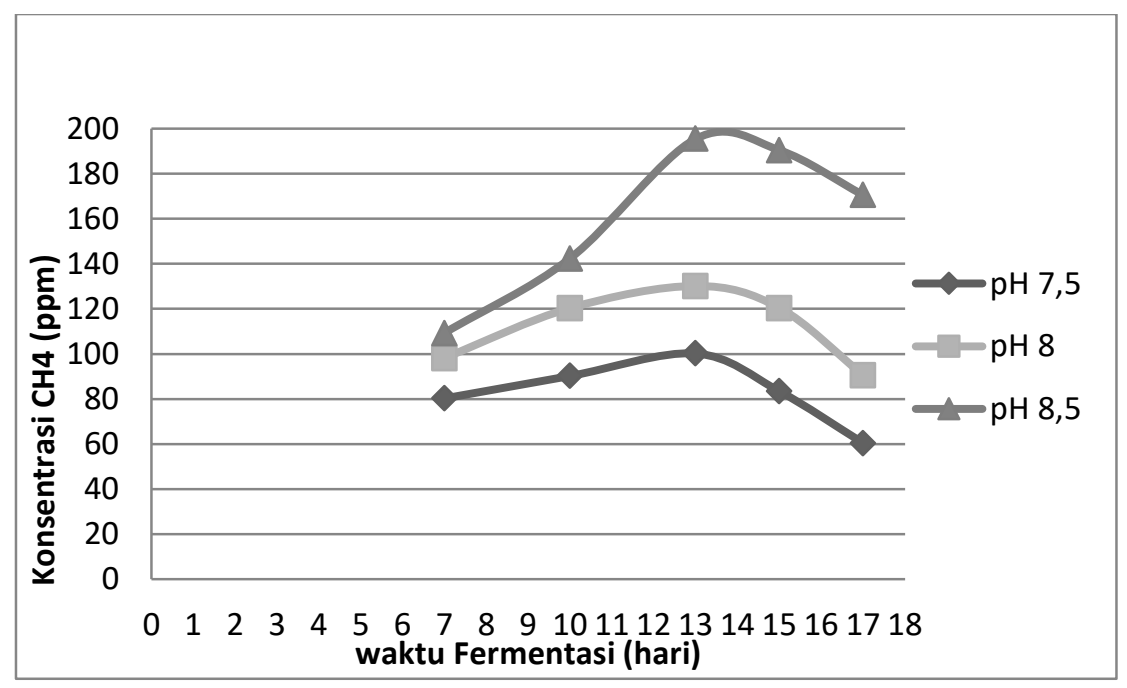

Gambar 2. Pengaruh pH terhadap produksi Biogas dengan Digester Berpengaduk

Gambar 2 menunjukkan pengaruh $\mathrm{pH}$ dan waktu tinggal dengan digester berpengaduk terhadap konsentrasi zat metana yang dihasilkan. Gas metana yang paling baik didapatkan pada kondisi pH 8,5 dan waktu fermentasi 13 hari yaitu sebesar 195,41 ppm.
Konsentrasi gas metana meningkat pada hari ke- 7 dan akan mengalami peningkatan sampai hari ke-13. Sedangkan gas metana yang paling kecil konsentrasinya didapatkan pada kondisi pH 7 dan waktu ferrmentasi 17 hari. 
Yaitu sebesar 60,4 ppm. Kondisi digester terus tertutup sampai hari ke-15.

Dari Gambar 2 dapat dilihat pada hari ke-15 dan akan terus menurun pada hari ke17, produksi biogas menurun hal ini disebabkan karena aktivitas bakteri metanogen terhambat akibat adanya penurunan $\mathrm{pH}$ dalam digester. Biogas akan tetap terbentuk pada hari ke-15 dan hari ke-17 karena adanaya larutan $\mathrm{NaOH}$ yang ditambahkahkan untuk menjaga agar larutan dalam digester dalam kondisi netral.

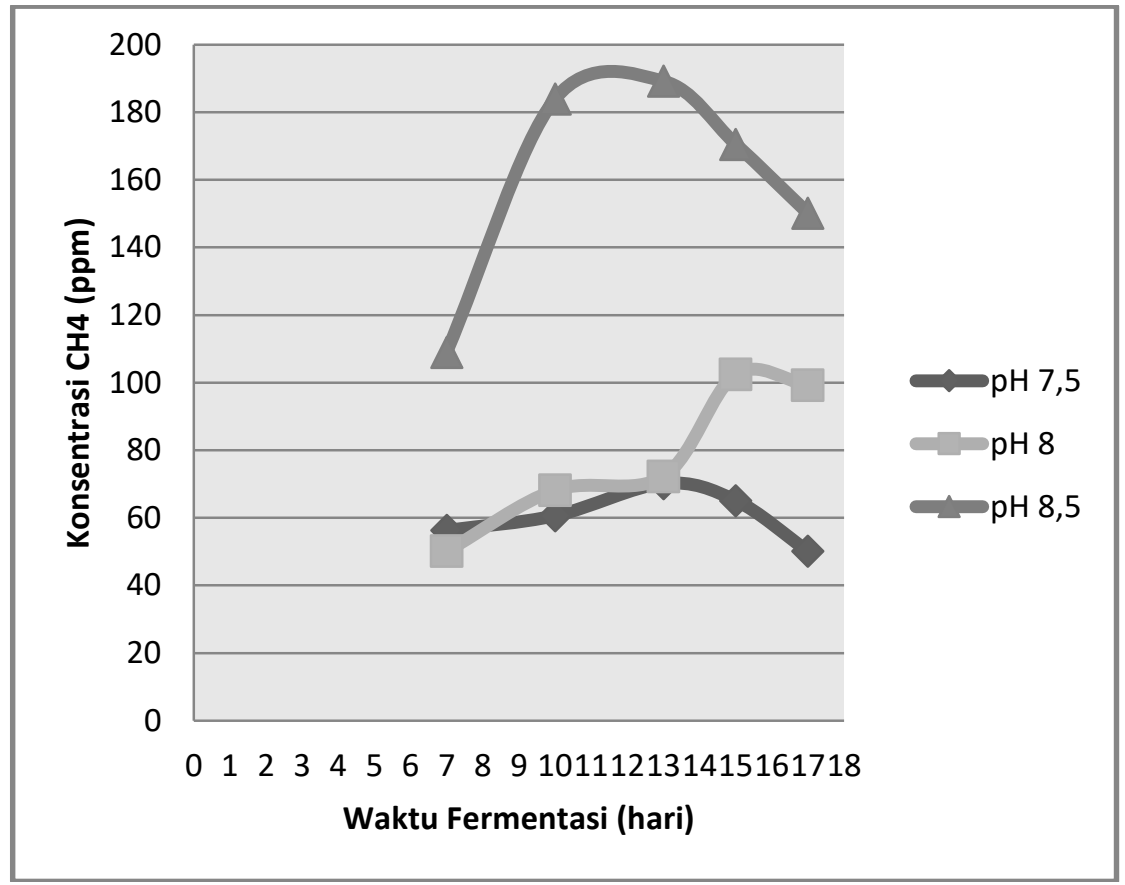

Gambar 3. Pengaruh pH terhadap produksi Biogas dengan Digester Tanpa pengaduk

Gambar 3 menunjukkan pengaruh $\mathrm{pH}$ dan waktu fermentasi terhadap konsentrasi gas metana dengan digester tanpa pengaduk. Gas metana paling baik dihasilkan pada kondisi pH 8,5 dan waktu fermentasi 13 hari yaitu sebesar 189,21 ppm. Sedangkan konsentrasi terkecil dihasilakan pada kondisi pH 7 dan waktu fermentasi 17 hari, yaitu sebesar 50,12 ppm. Sama seperti digester berpengaduk, hasil dai digester tanpa pengaduk juga mengalami peningkatan konsentrasi gas setelah hari ke-7 dan mengalami penurunan pada hari ke-15 dan ke-17.

Menurut Wahyuni (2011) ada tiga tahapan dalam pembentukan biogas, yaitu hidrolisis, asidogenik, dan metanogenik. Pada tahap asidogenik, terbentuk asam lemak yang dapat menurunkan $\mathrm{pH}$ digester. Bakteri pembentuk metana dapat dapat hidup pada rentang $\mathrm{pH}$ 7-9, oleh karena itu perlu dilakukan pengaturan $\mathrm{pH}$ agar keseimbangan antara reaksi pembuatan biogas dapat terjaga. Selain itu pengaturan $\mathrm{pH}$ dilakukan untuk menjaga agar larutan subsrat tidak telalu asam, karena bakteri metanogen merupakan bakteri yang sangat berperan dalam pembentukan biogas, bakteri ini sangat sensitif terhadap perubahan lingkungan, oleh karena itu kondisi lingkungan dalam digester harus benar-benar dijaga. Ada dua jenis fermentasi biologis, yaitu fermentasi aerob dan anaerob. Fermentasi aerob adalah fermentasi yang berlangsung dengan adanya oksigen, sedangkan fermentasi anaerob tanpa oksigen. Kondisi optimum pembentukan biogas akan lebih optium apabila fermentasi dilakukan dalam lingkungan anaerob (tanpa oksigen) ,karena bakteri metanogen hanya dapat hidup dalam kondisi tersebut. Pada percobaan, $\mathrm{pH}$ diatur hanya pada bagian awal, dan digester dibiarkan tertutup sampai waktu pengukuran konsentrasi.

Bakteri metanogen adalah bakteri yang berperan dalam pembentukan biogas. Bakteri ini memanfaatkan hasil dari proses asidogenik, yaitu asetat format, karbondioksida, dan hidrogen sebagai bahan pembentuk gas metana. Bakteri ini mempunyai morfologi yang beragam seperti methanothrix (Abdurachman et al, 2006). 
Pengaruh Pengadukan Terhadap Konsentrasi Biogas pada berbagai variasi pH

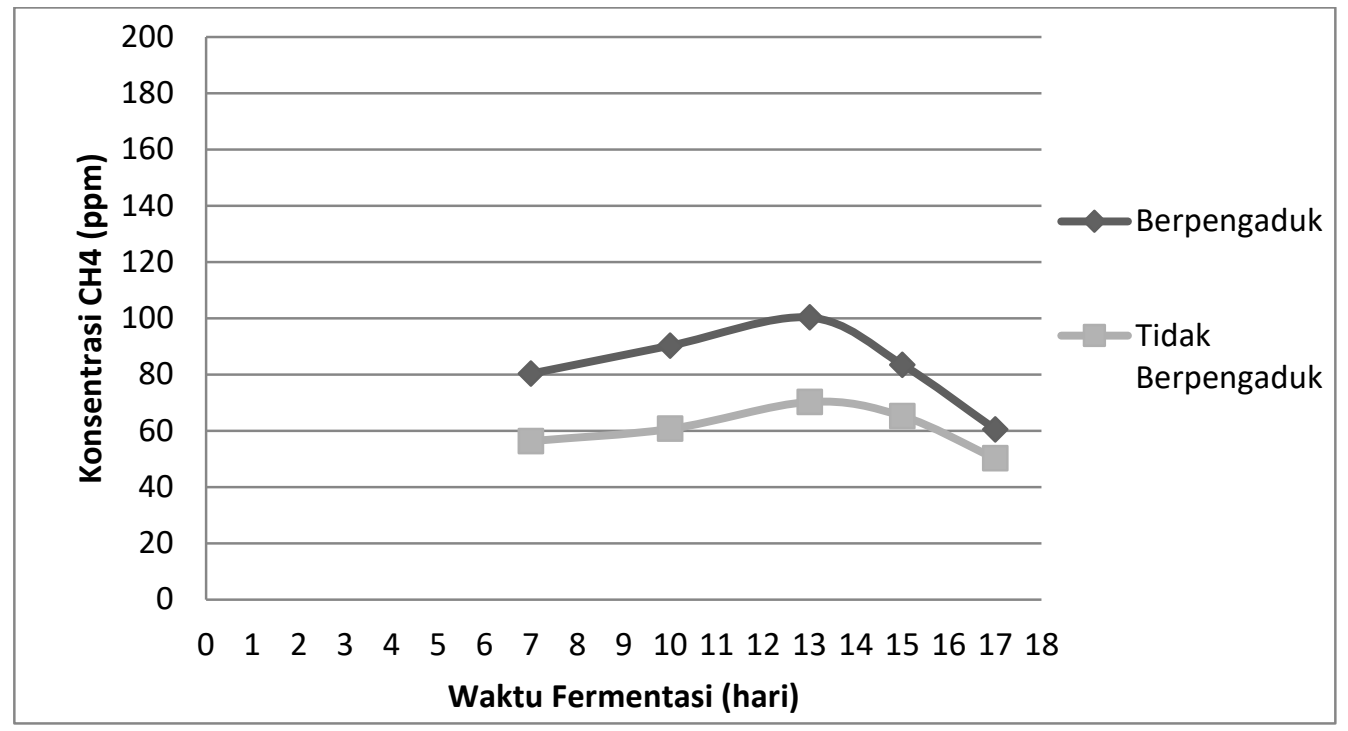

Gambar 4. Pengaruh Pengadukan Terhadap Konsentrasi Biogas pada pH 7,5

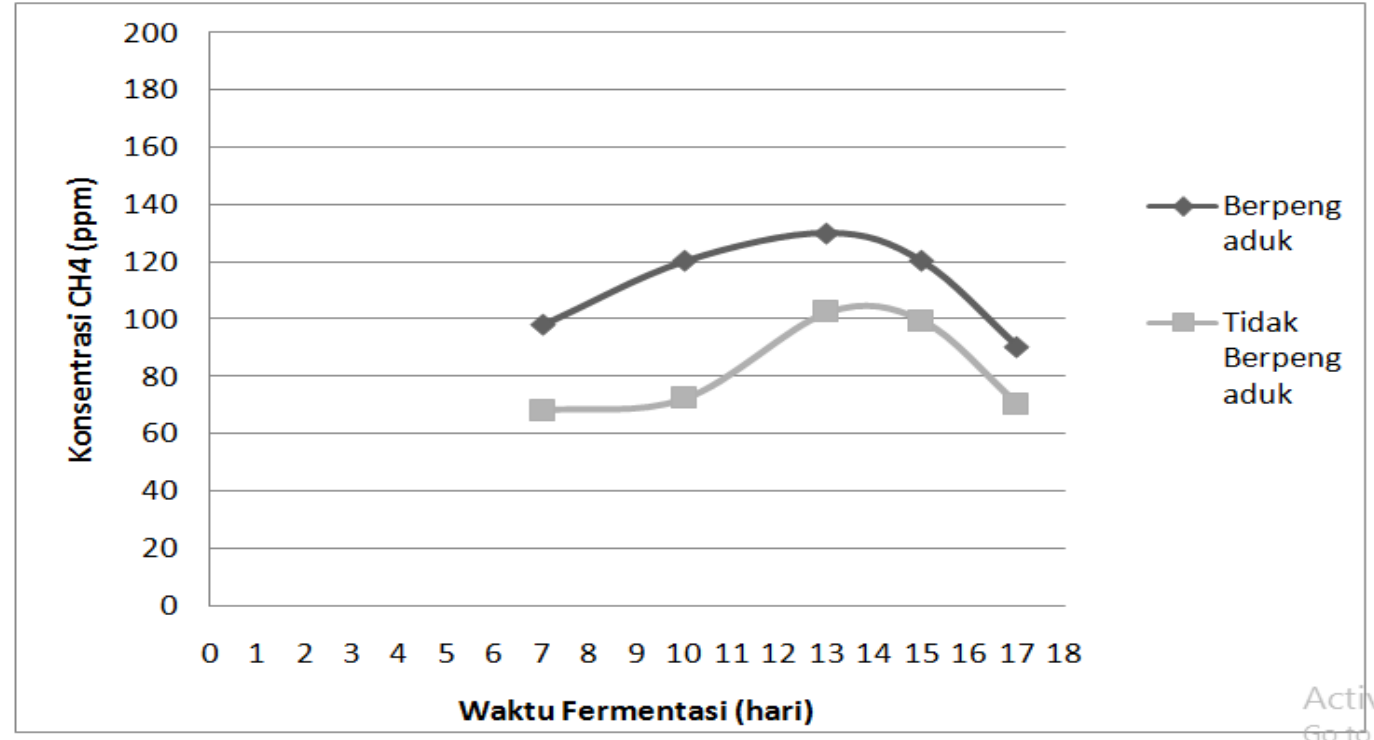

Grambar 5. Pengaruh Pengadukan Terhadap Konsentrasi Biogas pada pH 8 


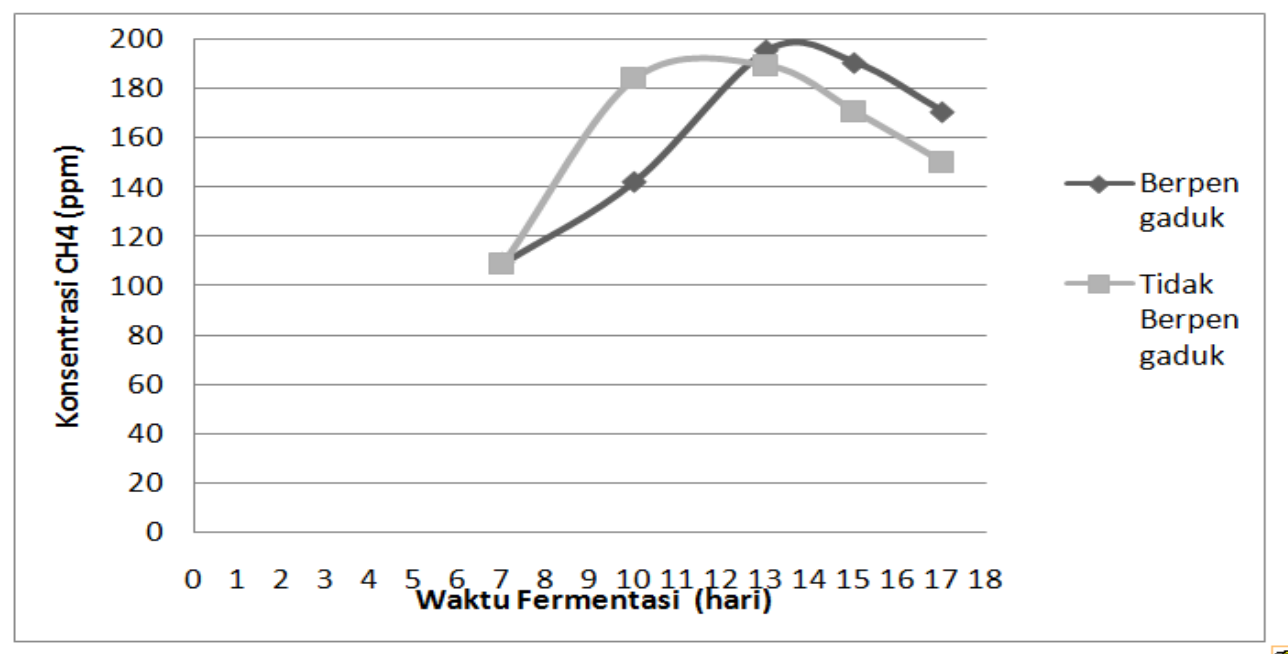

Gambar 6. Pengaruh Pengadukan Terhadap Konsentrasi Biogas pada pH 8,5

Gambar 4, 5 dan 6 menjelaskan pengaruh pengadukan terhadap konsentrasi biogas pada berbagai pH. Gambar 4 mengambarkan fermentasi biogas pada $\mathrm{pH} 7$, gambar 5 menggambarkan hasil fermentasi biogas pada $\mathrm{pH}$ 8, dan Gambar 6 menggambarkan hasil fermentasi biogas pada $\mathrm{pH} 8,5$.

Pengadukan sangat berpengaruh terhadap nilai konsentrasi gas metana, hal ini dapat dilihat pada Gambar 4, 5, dan 6 di atas, konsentrasi gas metana yang paling baik didapatkan dari digester berpengaduk baik pada kondisi pH 7,5; 8 dan 8,5. Pada pH 7,5 dan waktu fermentasi 13 hari, digester berpengaduk menghasilkan biogas sebesar 100,20 ppm, sedangkan digester tidak berpengaduk hanya menghasilkan 70,22 ppm. Sedangkan pada pH 8, digester berpengaduk menghasilkan biogas optimal 130,03 ppm sedangkan tanpa pengaduk optimalnya hanya 102,40 ppm

Menurut Rahayu dkk (2015) ada beberapa faktor yang mempengaruhi kualitas biogas diantaranya adalah temperatur, $\mathrm{pH}$, kelarutan gas, pengadukan, nutrisi, waktu tinggal.

Pengadukan pada digester akan memungkinkan kontak secara langsung antara mikroorganisme dengan bahan (substrat) pembentuk gas. Semakin tinggi frekuensi peengadukan, semakin tinggi pula kesempatan mikroorgansisme mendegradasi subsrat. Dengan menggunakan pengaduk. Gas-gas metana yang terperangkap dalam larutan dapat segera terlepas dan masuk ke penampung gas, karena pengadukan menghasilkan kontak yang cukup antara substrat dengan mikroorganisme dan menghasilkan kondisi homogen larutan limbah

Pengadukan umumnya dilakukan dengan menggunakan pengaduk mekanis, yaitu pengadukan cairan dengan memasukkan POME melalui pipa distribusi, atau pengadukan dengan menggunakan biogas yang diresirkulasi.

Selain pengadukan dan $\mathrm{pH}$, umpan yang masuk dan tersedia dalam digester juga harus diatur sedemikian rupa agar fermentasi berjalan dengan baik. Apabila substrat terlalu banyak, maka akan terjadi penghambatan pertumbuhan mikroorganisme (Speece,1996)

\section{KESIMPULAN}

Hasil dari penelitian diatas menunjukkan bahwa kondisi yang baik untuk menghasilkan biogas dari limbah cair kelapa sawit adalah pH 8,5 dengan waktu fermentasi 13 hari. Sedangkan Digester berpengaduk menghasilkan biogas lebih optimal dibandingkan dengan biodigester tanpa

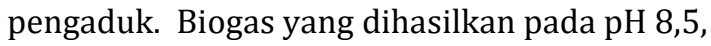
waktu fermentasi 13 hari dengan digester berpengaduk adalah 195,41 ppm.

\section{DAFTAR PUSTAKA}

Abdurachman, A., Haryati, U., dan Juarsah, I., 2006. Penetapan Kadar Air Tanah Dalam: Kurnia U.(eds). Sifat Fisik Tanah dan Metode Analisisnya. Balai Besar Penelitian dan Pengembangan Sumber Daya Lahan Pertanian. Badan Penelitian dan Pengembangan Pertanian. Departemen Pertanian, Bogor. 
Faizah Suryani, Ozkar Firdausi Homsah, Mahmud Basuki

Analisis pH dan Pengadukan Terhadap Produksi Biogas dari Limbah Cair Kelapa Sawit

DESDM, 2005, Diversifikasi Energi. Energi Kelautan sebagai Alternatif Baru. http://DESDM.go.id

Deublein, D. dan Steinhauster, A., 2008. Biogas from Waste and Renewabe Resources. An Introduction. WILEY-VCH Verlag $\mathrm{GmbH}$ \& Co. KGaA, Weinheim.

Direktorat Jendral Perkebunan, 2015, Statistik Perkebunan Indonesia. Jakarta Direktorat Perkebunan Indonesia.

Kementerian Lingkungan Hidup, 2017, Baku Mutu Limbah Cair Industri Minyak Kelapa Sawit. Jakarta:

Ngan, M.A., 2000. Management Of Palm Oil Industrial Effluents. Advance In Oil Palm
Research Vol. 2, Malaysian Palm Oil Board, Malaysia.

Rahayu, S., dkk., 2015, Buku Panduan Konversi POME Menjadi Biogas, USAID and Winrock Internasional.

Speece, R. E. 1996. Anaerobic Biotechnology For Industrial Wastewaters. Archae Press, Tennessee.

Sumirat, U (2009). Nitrous Oksida $\left(\mathrm{N}_{2} \mathrm{O}\right)$ Dan Metana $\left(\mathrm{CH}_{4}\right)$ Sebagai Gas Rumah Kaca. Jurnal TORSI Volume VII No 2, Juli 2009. Universitas Pendidikan Indonesia.

Wahyuni, S. 2011. Menghasilkan Biogas Dari Aneka Limbah. PT Argro Media Pustaka: Jakarta. 